\title{
O fechamento do estádio Engenhão em blogues de jornalistas esportivos: futebol, megaeventos e política
}

\author{
The closure of Engenhão stadium on sport \\ journalist's blogs: football, megaevents and politics
}

\begin{abstract}
Rafael Fortes | Universidade Federal do Estado do Rio de Janeiro (UNIRIO) Professor do Departamento de Ciências Sociais e coordenador do Laboratório de Comunicação e História (www.lachi.com.br). Integra também o corpo permanente do Programa de Pós-Graduação Interdisciplinar em Estudos do Lazer da Universidade Federal de Minas Gerais (UFMG).

E-mail: raffortes@hotmail.com

Luiza Aguiar dos Anjos | Universidade Federal do Rio Grande do Sul (UFRGS) Doutoranda em Ciências do Movimento Humano

E-mail: luizaaguiardosanjos@gmail.com
\end{abstract}

\begin{abstract}
Resumo
Este trabalho analisa textos sobre o fechamento do Engenhão pela Prefeitura do Rio de Janeiro publicados em blogues de veículos de comunicação com foco no esporte de 26/3/2013 a 17/6/2013. O artigo começa com a apresentaçáo dos blogues pesquisados e uma reflexão acerca do uso desta ferramenta de comunicação como corpus para a pesquisa científica. A análise do material se organiza em torno de quatro pontos: a discussão sobre legado; a discussão sobre custos e responsabilidade; a preocupação com a imagem do Brasil; as consequências para o Botafogo. Os jornalistas lançaram mão de distintas formas de contextualização para apresentar possíveis causas e consequências da medida, além de discutir as responsabilidades pelo ato e pela situaçáo anterior; o cenário macro de candidatura, organização e realização de megaeventos esportivos na cidade e no país; os problemas da administraçáo estatal e das entidades esportivas no Brasil; as relaçôes entre empreiteiras e poder público.
\end{abstract}

Palavras-Chave: megaeventos esportivos; internet; blogue; futebol; Rio de Janeiro

\begin{abstract}
This work analyzes texts on the subject, published in mainstream media blogs related to sport, from March 26, 2013 until June 17, 2013. The text presents a discussion about blogs and reflects on its use as corpus for scientific research. In the following, the analysis of the sources is organized over four points: sports megaevents and their legacy; assignment of responsibilities for what happened and for the costs; concerns over the image of Brazil; and consequences to Botafogo club. The jornalists resorted to various forms of contextualization to present possible causes and consequences of the measure, and to discuss the responsibilities by the act and the previous situation; the macro scenario of application, organization and implementation of sports megaevents in the city and in the country; the problems of state administration and sports entities in Brazil; the relationships between contractors and government.
\end{abstract}

Keywords: sports megaevents; internet; blog; football; Rio de Janeiro 


\section{Introdução}

Em 30 de junho de 2007, foi inaugurado o Estádio Olímpico Joáo Havelange, chamado popularmente de Engenhão. ${ }^{1} \mathrm{O}$ equipamento foi construído por meio de financiamento público para sediar as competiçóes de futebol e atletismo dos Jogos Pan-Americanos a se realizarem naquele ano na cidade.

A organizaçáo desta competição fazia parte de um projeto amplo, que abrangia a Copa de Mundo de 2014 e os Jogos Olímpicos de 2016 (Curi, Knijnik e Mascarenhas, 2011). Há quem aponte que a promoção de tais eventos está em sintonia com açôes em outros campos, integrando uma estratégia de promoção internacional do Brasil (Rubio, 2010; Almeida e Marchi Junior, 2014). Nas palavras de Vigevani e Cepaluni (2007), o primeiro governo de Luiz Inácio Lula da Silva adotou uma

estratégia que poderia ser batizada de 'autonomia pela diversificação', enfatizando a cooperação Sul-Sul para buscar maior equilíbrio com os países do Norte, realizando ajustes, aumentando o protagonismo internacional do país e consolidando mudanças de programa na politica externa (Vigevani e Cepaluni, 2007, p. 283).

Por exemplo, o fortalecimento das relaçóes com países da América do Sul, a realização de "acordos com parceiros não-tradicionais", a "retomada e estreitamento das relaçôes com os países africanos (...) [e a] campanha pela reforma do Conselho de Segurança das Naçóes Unidas, visando um lugar de membro permanente para o Brasil" (p. 283, 292). ${ }^{2}$ Uma fala do então presidente, em 2008, em discurso de apoio à candidatura do Rio de Janeiro aos Jogos Olímpicos, revela o esforço de colocar o país em nova posição no cenário internacional. Ele afirmou que

não se tratava de uma candidatura de "um país terceiro-mundista na busca de um espaço junto aos chamados paises desenvolvidos", reiterando que o Brasil "não é um paizinho qualquer", já que "em qualquer quesito [...] está entre os 10 maiores paises do mundo." (Almeida e Marchi Junior, 2014, p. 20).

Os insucessos em candidaturas olímpicas anteriores motivaram o plano de ter no Pan o exemplo de competência que contribuiria para a escolha do Rio pelo Comitê Olímpico Internacional (COI). ${ }^{3}$ Em texto escrito antes da decisão sobre a sede dos Jogos Olímpicos de 2016, embora crítico ${ }^{4}$ em relação aos megaeventos esportivos, Mascarenhas (2009) afirmou:

Outro aspecto positivo para o Rio de Janeiro é o conjunto de instalaçóes esportivas criado para o Pan 2007, amplamente considerado de alto nivel. Ao mesmo tempo, este evento foi avaliado como uma experiência (logistica) bem-sucedida, o que fortalece nossa candidatura. O próprio know-how adquirido com este evento nos habilita a realizar uma Olimpiada (Mascarenhas, 2009, p. 530).

A concretização desse projeto, com a escolha do Brasil e do Rio de Janeiro como sede dos megaeventos, veio acompanhada de discursos laudatórios e otimistas, mas também de posicionamentos críticos e desconfiados, tanto no plano jornalístico quanto no científico. ${ }^{5}$ 
Em março de 2013, um acontecimento acendeu os debates acerca dos legados deixados pelos megaeventos esportivos, e sobre a própria competência brasileira para realizá-los: a interdição do Engenhão. Consideramos que este episódio teve três principais protagonistas: a Prefeitura da Cidade do Rio de Janeiro, financiadora da obra e proprietária (Curi, 2012); as empresas responsáveis pela construção; e o Botafogo de Futebol e Regatas, clube que se tornou gestor do estádio ao vencer a licitação aberta em 2007.

Esse trabalho tem como objetivo analisar textos que trataram desse tema, publicados em blogues de veículos de comunicaçáa com foco no esporte, de 26/3/2013 a 17/6/2013. Na primeira data, a Prefeitura do Rio de Janeiro anunciou a interdição. Em 10/6/2013, através de decreto no Diário Oficial do Município, a Prefeitura determinou que o consórcio formado pelas empresas Racional, Delta e Recome e o consórcio Engenhão (formado por OAS e Odebrecht) deveriam começar as obras na cobertura do estádio. ${ }^{6}$ Concluindo o recorte temporal em 17/6/2013, uma semana após a publicação do decreto, acreditamos cobrir a maior parte dos textos divulgados sobre o assunto nos referidos blogues.

O texto se organiza em duas partes. A primeira descreve o percurso metodológico, apresenta os blogues selecionados e reflete acerca do uso dessa ferramenta de comunicação como corpus para a pesquisa científica. A segunda analisa o material empírico, articulando-o com a discussão de quatro temas: os megaeventos esportivos e seus legados; a atribuição de responsabilidades pelo ocorrido e pelos custos; a preocupação com a imagem externa do país; e as implicações da interdição para o Botafogo.

\section{Caminhos metodológicos e os blogues como objeto de pesquisa}

Em meados de 2014, realizamos um levantamento em sites: de emissoras de rádio AM e jornais diários da cidade do Rio de Janeiro; e de canais esportivos de TV por assinatura e portais de internet. Buscamos na lista de blogues e na editoria de esportes aqueles que tivessem conteúdo voltado para cobertura do futebol fluminense e/ou bastidores do esporte. ${ }^{7}$ Encontramos 41 blogues, ${ }^{8}$ distribuídos nos seguintes sites (o total de cada site está entre parênteses): ESPN/ESPN Brasil (12), Extra (1), Fox Sports (9), O Globo (3), Lancenet (7), Rádio CBN (5), Rádio Globo (2) e Sportv (2). Dos 41 blogues, 18 tiveram ao menos um texto mencionando o fechamento do Engenhão. $\mathrm{O}$ universo investigado totalizou 54 textos.

A não ocorrência de notícias em 23 blogues se explica por três motivos principais: a) o blogue não continha uma seção arquivo que apresentasse cronologicamente os textos e/ou um mecanismo que permitisse busca por palavras-chave; b) o blogue contava com arquivo, mas não continha textos referentes ao período desejado (ou havia sido criado após junho de 2013); c) o blogue continha arquivo e textos referentes ao período desejado, mas nenhum destes abordava o fechamento do Engenhão. Há ainda fatores que não são decisivos, mas influem no maior ou menor interesse pelo futebol fluminense, como: o jornalista trabalhar no RJ ou em outro estado; e a emissora (sobretudo nos 
canais de TV por assinatura) transmitir ou não aquele estadual. Retomamos esta discussão nas consideraçóes finais.

Os seguintes sites foram pesquisados e não continham blogues que se enquadrassem nas caraterísticas mencionadas: Band Sports, O Dia, Rádio Bradesco Esportes, Rádio Band News, Rádio Manchete, Rádio Tupi. No que diz respeito aos quatro principais portais, uma visita à lista de blogues evidenciou escassez de material que servisse à pesquisa: Globo.com não tem blogueiro que se dedique a esporte; IG tem apenas um blogue sobre "bastidores do futebol” (Blog do Jorge Nicola); Terra não tem blogueiros nem colunistas de esporte; UOL tem vários blogues sobre esporte, mas nenhum que se dedique ao Rio de Janeiro.?

Passamos à discussão de algumas características deste universo, relacionando-as a trabalhos sobre a pesquisa de blogues em Comunicação. Em primeiro lugar, chama a atenção a pouca atenção ao esporte entre os autores que se debruçaram sobre o tema. Dos 140 trabalhos listados no estado da arte elaborado por Amaral, Recuero e Montardo (2009b), nenhum aborda o esporte, o qual tampouco é mencionado pelas autoras como um tema de investigação. Ele é mencionado apenas duas vezes em toda a obra (Amaral, Recuero e Montardo, 2009a).

A sociabilidade e as trocas proporcionadas pelos comentários são um dos aspectos destacados pelos estudiosos (Amaral, Recuero e Montardo, 2009b). Optamos por não analisar os comentários dos leitores, por três motivos: o número total é reduzido; o conteúdo não nos pareceu promissor, em termos de fornecer subsídios para análise ${ }^{10}$; e vários blogues pesquisados não os permitem.

De acordo com as mesmas autoras, a personalização também é considerada relevante pelos pesquisadores. Dos 41 blogues investigados, apenas dois eram claramente atribuídos a mais de uma pessoa. Considerando que todos estão hospedados nos sites dos veículos de comunicação em que os jornalistas trabalham, por um lado, podemos afirmar que, na maioria dos casos, o aspecto pessoal (no sentido de individual) se mantém; por outro, o mesmo náo ocorre com a questão da personalização tal qual destacada pela bibliografia (Amaral, Recuero e Montardo, 2009b). Isto tanto pela estrutura padronizada (em geral, todos os blogues de um veículo têm o mesmo layout) quanto por possíveis constrangimentos e regras (não se trata de escrever qualquer texto, em qualquer linguagem, sobre qualquer assunto), tendo em vista se tratar de tarefa profissional.

A característica de "redes sociais constituídas através das trocas de comentários e links" é nula: ambos praticamente inexistem (Amaral, Recuero e Montardo, 2009b, p. 37). O principal fator que confere visibilidade a estes blogues é o fato de estarem vinculados aos sites de veículos e emissoras de comunicação nos quais trabalham os jornalistas que são seus autores. Observamos que seu conteúdo pode ser a mera reprodução do trabalho realizado em outras mídias - como no caso dos blogues que se limitam a replicar as colunas publicadas em um jornal diário, por exemplo -, textos originais, ou ambos. ${ }^{11}$ Quando se trata de reprodução, é sempre de colunas (e não de reportagens, por exemplo). ${ }^{12}$ 
Do ponto de vista laboral e de classe, há que se pensar no que representa esta nova tarefa para o profissional em meio à rotina árdua das redaçóes. $\mathrm{O}$ fato de alguns veículos terem dezenas de blogues em seus sites sugere que, no âmbito das grandes empresas de comunicação, essa ferramenta converteu-se em mais uma atividade imposta aos trabalhadores, sem a contrapartida de reajuste ou adicional no contracheque. Evidentemente, é possível que alguns jornalistas gostem de escrever em blogues, apreciem a interlocução com os leitores, tenham um retorno positivo em termos de autoestima (em funçáo dos comentários, do compartilhamento dos textos e das estatísticas de acesso) e de novas oportunidades profissionais etc. Desejamos, contudo, chamar a atenção para aspectos estruturais da incorporação desta ferramenta no âmbito das relações de trabalho sob um regime de exploração capitalista - aspecto em geral ausente das reinvindicaçóes e preocupaçóes centrais das entidades de classe dos jornalistas brasileiros, cuja atenção, desde a virada do século, foi praticamente monopolizada pela luta pelo (re)estabelecimento da obrigatoriedade de diploma universitário específico para o exercício da profissão de jornalista; e também ignorado em trabalhos científicos de Comunicação que tratam do tema. Por exemplo, embora apontem que "na Alemanha, blogs de jornalistas não são tão comuns como no Brasil (...). As razóes para isso seriam a falta de tempo e de uma remuneração extra por esse trabalho, além da desconfiança e falta de conhecimento sobre o assunto", Quadros e Sponholz (2006, p. 3) não discutem a questão.

Muito poderia ser dito quanto às condições de produção, o que foge ao foco deste artigo. Voltemos a ele, passando à análise do corpus.

\section{Legado e megaeventos}

O primeiro tema de discussão em torno dos legados diz respeito ao fato de o Engenhão ter sido construído para os Jogos Pan-Americanos de 2007. Ele é chamado de o "maior símbolo do 'legado' do Pan” (Prado, 2/04/2013) e a “joia da rainha do Pan” (Malia, 7/06/2013). Um dos artifícios usados foi lançar máo de ironia para apontar a contradição entre os problemas com os equipamentos construídos para aquele evento e o discurso ufanista das autoridades nos anos que o antecederam:

Some-se a isso [à interdição do Engenhão] a informação de que a natação no Júlio Delamare também foi para o beleléu, mais a demolição do Célio de Barros, assim como o fim do Velódromo, e eis que, como nunca, a três anos da Olimpiada brasileira, estamos formando uma cultura olimpica, como nos foi prometido pelo presidente do COB e do CoRio. (KFOURI, 2013, online) 15

O jornalista argumenta que, longe de se tratar de um caso isolado, o Engenhão faz parte de uma regra: a das promessas não cumpridas em relação à utilidade dos equipamentos esportivos construídos para o evento. Os exemplos citados demonstram que a infraestrutura para a realização de um megaevento não constitui necessariamente um legado positivo. Equipamentos excessivamente grandes ou cujo uso não corresponde aos interesses da cultura local podem significar um problema por gerarem altos custos de manutenção, sem um retorno à 
altura para a comunidade (Jago et alli, 2010). Esse problema, segundo Jago et al. (2010), pode ser evitado se a organizaçáo do megaevento for considerada dentro do plano de desenvolvimento a longo prazo da cidade. Os autores afirmam, contudo, que isso raramente é feito e que a organização realizada em uma perspectiva de curto prazo - e com frequência pulando etapas por falta de tempo hábil - faz com que os benefícios potenciais poucas vezes sejam alcançados. Ademais, o legado de um megaevento esportivo envolve uma série de aspectos além dos equipamentos construídos ou reformados para a realização das competiçóes, podendo ser tanto positivos quanto negativos (Girginov, 2011; Jago et alli, 2010; Pampuch, Almeida e Marchi Junior, 2012). ${ }^{16}$

Colocando o ocorrido no contexto amplo de preparação para os megaeventos, alguns blogues levantam a possibilidade de os erros que levaram à interdição do Engenhão estarem se repetindo nas obras então em curso, sobretudo relativas ao Mundial de 2014: "Quem garante que os estádios da Copa não estão sendo erguidos ou reformados da mesma forma?" $17 \mathrm{O}$ principal argumento apresentado para sustentar a hipótese é o envolvimento das construtoras responsáveis pelo Engenhão em outras obras: "E o Maracanã? Não são os mesmos?". ${ }^{18}$ Pressa e má realização foram comumente apontadas como "características"19 que poderiam acontecer de novo: "O Engenhão é mais um de tantos casos. Não um caso desastrado de engenharia. Mais um caso de falta total de zelo. E que se repete. Ontem, hoje e amanhã." (BECHLER, 28/03/2013) ${ }^{20}$

Ainda no contexto dos megaeventos, criticou-se o fato de o estádio, apesar do custo de construção (ver próxima seção) e de se encontrar interditado para conserto da cobertura, necessitar de outras obras para 2016:

Projetada para receber uma Olimpíada, a arena é chamada de estádio olímpico. [...]
Mas para abrigar os Jogos de 2016 teria que passar por nova reforma, fora a questão
da cobertura. Precisaria de mais lugares - pelo menos 12 mil-, além de equacionar a
questão do estacionamento e do transporte público até o estádio e resolver seus problemas
estruturais. (KFOURI, 2013, online)

Um jornalista aprofundou esta discussão sobre que obra realizar, tendo em vista a necessidade de consertar a cobertura e de ampliar a capacidade de público para a Olimpíada. Uma das possibilidades apresentadas foi que ambas fossem realizadas simultaneamente. ${ }^{22}$

Um argumento frequentemente usado para ressaltar a gravidade do fechamento foi que o Engenhão se tornara o "principal palco do futebol carioca, desde o início das obras do Maracanã, em 2010”23 e seu fechamento "deixa[ra] o Rio sem lugar decente para os jogos de seu campeonato." ${ }^{24}$ Em meio ao campeonato estadual, a capital ficou sem espaço adequado para as partidas entre os quatro principais clubes, pois os maiores estádios em uso - São Januário e Moça Bonita - não estavam autorizados pela polícia militar a receber clássicos. ${ }^{25}$ Tal situação, problemática em si, foi considerada por alguns jornalistas ainda mais grave justamente por ser a cidade sede de competiçóes internacionais e pelo volume de recursos gastos em equipamentos esportivos. ${ }^{26}$ Tais textos inserem o fechamento do estádio e a situação decorrente num contexto amplo de crise do futebol e da 
administração pública brasileiros. Devido às rotinas produtivas e outros fatores, tal contextualização e extensa argumentação é rara no jornalismo diário - sendo uma possibilidade interessante para os blogues. ${ }^{27}$

O imbroglio em torno do estádio também foi relacionado à qualidade do campeonato estadual de futebol profissional: "O Carioca 2013 foi esquecível por vários motivos: inchaço habitual, baixo nível técnico, estádios vazios, interdição do Engenhão (...)"28. Renato Mauricio Prado lançou mão de ironia, sugerindo que, "com o Engenhão interditado e o estádio do Volta Redonda rachado, periga a final do Estadual ser disputada no Aterro do Flamengo, como preliminar do clássico entre os garçons do Porcão e os do Belmonte. Dá-lhe, Rubinho!”

Outros sugeriram que o objetivo da construção fora auxiliar a candidatura da cidade a receber os Jogos Olímpicos:

O Estádio Olimpico João Havelange, nomenclatura apropriada, custou $R \$ 400$ milhöes para uma só missão: ajudar o Rio de Janeiro a ser sede das Olimpiadas. Se tudo se desintegrar menos de seis anos depois, não tem problema. Talvez até já estivesse combinado. (KFOURI, 2013, online) ${ }^{30}$

O trecho permite pensar a decisão de erguer tal equipamento esportivo e de fazê-lo nas condiçóes e da forma como se fez - como um meio, e não um fim. De acordo com esta perspectiva, não haveria motivo para surpresa, pois os resultados eram coerentes com os objetivos: produzir um continuum de gastos, que incluiria novas obras para a Olimpíada no Engenháo (reformado entre 20132015) e no Maracanã (fechado para reformas entre 2010 e 2013). ${ }^{31}$

Em raras ocasióes abordou-se a questão dos posicionamentos a respeito dos megaeventos esportivos, em particular os das próprias empresas de comunicação e de seus funcionários, os jornalistas. De acordo com os autores que o fizeram, quem aponta os problemas, erros e crimes é considerado "baixo astral" 32 por um jornalismo esportivo que optou por ignorar questôes espinhosas e que tentava criar um clima de empolgaçáa ${ }^{33}$ com a seleção brasileira e a Copa das Confederações. ${ }^{34}$ Voltaremos a esta questão nas consideraçôes finais.

\section{Responsabilidade e custos}

A discussão sobre a responsabilidade pelos problemas do estádio aparece vinculada a dois aspectos: os acontecimentos que antecederam o fechamento e os custos.

Interditado desde 26 de março, o Engenhão ficará fechado, para reformas, durante um ano e meio, a partir do início das obras. É a confirmação de um escândalo do tamanho do estádio. Que estourou o orçamento original absurdamente (de $R \$ 60$ milhöes saltou para $R \$ 380$ milhóes) e nem sequer foi bem feito. (PRADO, 2013, online) $)^{35}$

Primeiro, a menção ao custo ocupa lugar central na argumentação: tal como vários textos pesquisados, este aponta a discrepância entre os valores do orçamento inicial ( $\mathrm{R}$ \$ 60 milhóes) e do custo final ( $\mathrm{R}$ \$ 380 milhóes). ${ }^{36}$ 
Longe de ser um caso isolado, a atualização de custos de arenas esportivas construídas ou reformadas nos últimos anos tornou-se um padrão. Damo e Oliven (2013), comparando os custos dos estádios para a Copa estimados em 2009 (quando da definição das cidades-sede) e em abril de 2013, evidenciaram um significativo aumento em dez dos onze equipamentos ${ }^{37}$ - em dois casos, superior a $100 \%$. Os autores levantam a possibilidade de que os valores iniciais tenham sido deliberadamente subestimados a fim de evitar a ira popular. A idoneidade de tais correções também é vista com desconfiança, pois as empresas que realizaram as obras são tradicionais prestadoras de serviços dos governos e têm longo histórico de financiamento de campanhas políticas (Damo e Oliven, 2013).

No trecho citado, tanto o gasto além do orçado quanto a obra mal executada são vistos como uma forma de desperdício de dinheiro público. Argumenta-se que, se o alto custo e o superfaturamento são um problema absoluto, a interdição converteu-os também em problema relativo: gastou-se tal valor num estádio que "nem sequer foi bem feito". Houve ainda textos que remeteram aos discursos de dirigentes políticos e esportivos que prometiam que os estádios seriam construídos com dinheiro privado. ${ }^{38}$

Paralelamente à desconfiança relativa à honestidade dos orçamentos, existe uma crítica que não é centrada nas altas cifras empreendidas para a realização de megaeventos no Brasil. Analisando tais contestaçóes, Damo e Oliven (2013) defendem que, mais do que uma posição de ordem econômica, essa questão parece ter cunho moral. Tomando as críticas aos valores empreendidos nas construçôes e reformas dos estádios, os autores defendem que, ao contrário do que afirmam alguns argumentos contestatórios, tais cifras dificilmente promoveriam mudanças significativas em áreas em que o Brasil apresenta graves problemas. Assim, a discussão parece partir notadamente de uma percepção generalizada de que os investimentos realizados são concentrados e definidos por uma elite econômica e política que, por sua vez, será a maior beneficiada pelo evento.

Tal como outros, um jornalista formulou perguntas:

Como é possivel que um estádio construido há menos de sete anos apresente problemas estruturais? O que dizem a Odebrecht e a $O A S$, responsáveis pelo consórcio que ergueu a obra? O que dizem os dirigentes do Botafogo, responsáveis pela manutenção do Engenhão? (PRADO, 2013) 39

Chamamos a atenção para quatro pontos nesta citação. Primeiro, o destaque dado ao tempo decorrido entre a inauguração e a interdição, algo presente em vários textos. Segundo, creditar uma parcela de responsabilidade aos dirigentes do Botafogo, algo raro até nos textos que abordam os impactos para o clube (ver item 3.4). Terceiro, a atribuição clara de responsabilidade às empreiteiras que integravam o consórcio que realizou a construção. Quarto, o uso de perguntas como recurso para discutir os assuntos. Esta prática pareceu-nos 
particularmente presente em blogues de jornalistas de destaque, ${ }^{40}$ como Renato Maurício Prado e Luiz Penido. ${ }^{41}$ Por um lado, a maneira como as perguntas são formuladas e seu conteúdo indicam que, pela posição que ocupam, tais profissionais podem fazer críticas às vezes contundentes, num espaço editorializado. ${ }^{42}$ Este tipo de posicionamento explícito raramente se dá nos espaços noticiosos regulares e por parte de jornalistas novatos. Além disso, formular perguntas pode ser uma estratégia para criticar evitando fazer afirmaçóes que poderiam ser interpretadas como acusaçóes, possibilitando a abertura de processos judiciais contra o autor. Por outro, este recurso dá o que pensar em relação ao próprio ofício jornalístico. Afinal, ao que parece, as perguntas lançadas ao ar não chegam a ser feitas (nem pelos jornalistas-blogueiros, nem pelos repórteres dos veículos em que trabalham) a quem poderia e caberia respondê-las, para depois se apresentar o resultado ao público. Nisso consiste, em parte, o próprio fazer jornalístico, como indica outro texto: "Não sou engenheiro e nem advogado especialista. Não sei fazer outra coisa além de ouvir as partes envolvidas do que, na minha opinião, é um escândalo no Rio de Janeiro.”³3 O trecho sugere que os conhecimentos técnicos necessários para travar uma discussão aprofundada não são dominados pelos jornalistas, a quem caberia ouvir os especialistas. Em todas as passagens que apresentaram esta contraposição de tipos de conhecimento, o argumento se assemelha: o fato de não deter o saber necessário para discutir as questôes técnicas de forma alguma impedia que o jornalista percebesse o que estava acontecendo. Houve momentos em que se afirmou que qualquer um poderia abordar o assunto:

É necessário ter conhecimento técnico para tratar de projetos, equivocos, fissuras, riscos de desabamento. Não temos essa pretensão. Mas para falar de superfaturamento, obras apressadas, pressáo politica e chuva de dinheiro público durante o processo, basta ser curioso. (KFOURI, 2013) $)^{44}$

Tais afirmaçôes são notáveis, tendo em vista a opacidade que reveste a maior parte da produção jornalística: raramente ela debate seu próprio papel, bem como que elementos constituem a identidade jornalística - mesmo as entidades de classe são pouco afeitas a esta discussão (Albuquerque, 2006). Além disso, nas ocasióes em que isto acontece, geralmente os jornalistas e demais debatedores apresentam argumentos díspares e por vezes contraditórios em torno do que caracterizaria a atividade e seu caráter profissional (Albuquerque e Soares, 2004; Fortes e Albuquerque, 2006). Raramente, como neste caso, argumentam que a tarefa de abordar os assuntos pode ser realizada por qualquer pessoa que dotada de curiosidade.

Autoridades governamentais e esportivas também foram bastante criticadas:

A cada dia que passa são revelados mais "podres" do Engenhão — reportagem do Globoesporte.com denuncia material de construção vagabundo; sistema elétrico deficiente; parte hidráulica em condiçóes deploráveis; telóes de quinta categoria e por aí 
vai. Quanto mais se mergulha na nebulosa história da construção do maior símbolo do "legado" do Pan, mais se evidencia a escandalosa irresponsabilidade de nossos políticos e dirigentes esportivos. (PRADO, 2013)45

Contudo, a ampla maioria dos textos fica no plano das críticas e constataçôes genéricas. Os únicos que apresentaram dados e os contextualizaram de forma a sustentar a argumentação foram os de Paulo Vinicius Coelho. Por exemplo, abordando o papel das empreiteiras nas obras do Engenhão e do Maracanã:

OAS e Odebrecht assumiram a construção justamente no momento de fazer a cobertura, porque a Delta assumiu sua incapacidade de fazer essa parte da obra. $\mathrm{Na}$ época, não havia incapacidade financeira da construtora.

Reportagens indicam que desde o ano 2000 a Delta foi beneficiada por obras do governo do Estado que chegaram a $R \$ 2$ bilhóes. A Delta saiu do Engenhão justamente no momento de levantar a cobertura, por admitir sua incapacidade para tocar a obra! E, mesmo assim, participou com 30\% do consórcio da reforma do Maracanã, do qual anunciou sua saída também antes da conclusão, em abril do ano passado!

Se a Delta desistiu do Engenhão antes de sua conclusão, como ninguém discutiu sua entrada no consórcio do Maracanãe? A resposta é óbvia, passa pelas relaçôes políticas o que torna tudo mais absurdo quanto mais se pensa a respeito. (COELHO, 2013) ${ }^{46}$

O texto apresenta questôes que não apareceram em qualquer outro e aponta a ingerência entre relaçóes políticas e comerciais como um problema. Ou seja, a interdição possibilita o aparecimento de denúncias sobre questôes que não dizem respeito especificamente às falhas da construção, mas às articulações entre governantes e empresários que envolveram esta e outras obras no estado do Rio de Janeiro, que extrapolam o âmbito esportivo. Além disso, apresenta dados e posiçóes - como afirmar claramente que a construtora Delta recebera recursos públicos bilionários e que depois alegara incapacidade financeira ao abandonar a obras dos dois estádios, $-{ }^{47}$ que, se tanto, são apenas insinuados em outros textos.

Alguns textos apontaram a dificuldade de identificar os responsáveis: “impossível atribuir responsabilidade com certeza à Engenharia, à Arquitetura, à Prefeitura ou ao Botafogo" (COELHO, 2013, online). ${ }^{48}$ A maioria cobrou que isto fosse feito, com a subsequente aplicação de puniçôes, embora muitos desacreditassem que de fato providências seriam tomadas e alguém chegaria a ser condenado pela Justiça: "Isto posto, segue o baile: até agora, os nobres portôes de Bangu 1 não se abriram para recepcionar pelo menos um dos muitos gênios que levantaram a faraônica obra com o seu, o meu, o nosso rico dinheirinho.”’’99

Em raros casos, cobraram-se explicações em relação à situação imediatamente anterior ao fechamento: "Mas e os motivos de acontecer só agora? As autoridades não estão isentas de responsabilidade e de explicações ao público que colocou sua cabeça lá embaixo, e correu riscos de um eventual acidente (...)" (MALIA, 2013, online). ${ }^{50}$ 
A decisão da Prefeitura recebeu diferentes avaliaçóes, que agrupamos em três categorias:

a) Referendá-la integralmente: "Antes de mais nada, quero deixar claro que apoio totalmente a atitude do prefeito Eduardo Paes." (CASTELLAR, 2013, online) $)^{51}$

b) Criticar frontalmente: "O prefeito agora fala grosso. Sabia de tudo, sempre soube. Há tempos recebeu relatório dando conta que o 'modelo matemático utilizado para calcular a estrutura do teto não se cumpre’. Deixou rolar." (CASTRO, 2013, online) ${ }^{52}$ Alguns textos afirmaram ou sugeriram que a interdição poderia ter sido indevida. Para tanto, três argumentos foram mobilizados: ${ }^{53}$ 1) A interdição seria benéfica para os administradores do Maracanã; 2) Ventos de $90 \mathrm{~km} / \mathrm{h}$ haviam ocorrido no Rio de Janeiro sem provocar dano nos arcos (segundo alguns textos, o laudo que deu sustentação à interdição afirmava haver risco de queda com ventos de velocidades inferiores); 3) Apresentação de um relatório da Abace (Associação Brasileira de Engenharia e Consultoria Estrutural) que rechaça o relatório apontando risco da estrutura do Engenhão. (HABID, 2013, online) $)^{54}$

c) Criticar os problemas do estádio, mas admitir que, no curto prazo, a interdição era a única saída: "Pelo menos descobrimos antes que caísse que a cobertura do estádio João Havelange [...] estava condenada”. (BETING, 2013, online) $)^{55}$

Percebemos em grande parte do material analisado uma postura de desconfiança e descrença com relação à competência e honestidade dos dirigentes responsáveis pela gestão tanto estatal quanto das entidades esportivas nacionais. A interdição é vista como um sintoma de uma já conhecida administração problemática das instituiçóes. Alguns autores generalizam:

O que é desesperador em relação ao escândalo do Engenhão - mesmo no país dos escândalos semanais, este merece a qualificação - é não saber em quem acreditar. Vejamos os envolvidos. César Maia, Sérgio Cabral, Eduardo Paes, Carlos Nuzman. Todos são políticos brasileiros e, como tais, não merecem confiança. Porque no DNA dos nossos politicos profissionais, o modo de operar é um só: utilizar o interesse público como plataforma, esquecê-lo ao chegar ao gabinete, e capitalizar. Capitalizar muito. (KFOURI, 2013, online) $)^{56}$

Esse discurso que generaliza negativamente sobre o universo da política é recorrente nos veículos de comunicação hegemônicos do Brasil. E, como nesse caso, extrapola o âmbito da cobertura específica do tema. Essa visão negativa a respeito do país também é abordada na próxima seção.

\section{Imagem do Brasil}

Diversos textos defenderam a ideia de que um acontecimento como a interdição prejudicava a imagem do país, cuja valorização internacional é um dos maiores motivos para a realizaçáo dos megaeventos esportivos. $\mathrm{O}$ trecho a seguir exemplifica este ponto de vista: 
Grandes eventos, como a Copa do Mundo e as Olimpiadas, podem ser grandes oportunidades para desenvolver cidades e fazer propaganda positiva dos paises que as sediam. Isso, claro, se as obras e tudo que as cerca, em termos de infraestrutura, forem bem feitos. Absurdos como esse do Engenhão arranham a nossa imagem e, em vez de ganharmos, corremos sério risco de acabar perdendo. Muito. Que turista terá vontade de voltar, desembarcando em aeroportos de quinta categoria, como os nossos, e sabendo que alguns estádios daqui correm risco de desabamento ao sabor dos ventos? (PRADO, 2013, online $)^{57}$

Para discutir o tema, acreditamos ser útil o argumento de Fico (1997), para quem

"a preocupação com a imagem do Brasil no exterior é uma das principais fontes de alimentação da tradição do pessimismo no Brasil” (FORTES, 2015, p. 45). ${ }^{58}$

Houve textos que identificaram o discurso de autoridades políticas como origem do argumento de que os megaeventos esportivos contribuiriam para melhorar tal imagem, o que, por sua vez, supostamente justificava os gastos realizados:

Li, com a maior atenção, artigo assinado pelo ministro do Turismo falando com esperança, quase otimismo, da decisáo brasileira de embarcar "na dispendiosa aventura de sediar uma Copa do Mundo". É um artigo honesto, simpático, bem pensado, muito diferente dos discursos vazios de seu colega ministro dos Esportes. Em sintese, justifica os 34 bilhóes de reais que estamos gastando para a grande festa do ano que vem. Acredita ele, o ministro do Turismo, que quatro vezes poderemos ganhar, a longo prazo, só com as melhorias que vem sendo feitas com o pensamento no eventual visitante. (MÁXIMO, 2013, online $)^{59}$

Ao que parece, o jornalista aceita o argumento do ministro: se os gastos servirem para o objetivo anunciado, relativo ao futuro, menos mal. Não obstante, critica os problemas do presente, que incluem o Engenhão:

Entre os legados (palavra tão gasta nestes tempos pré-Copa e pré-Olimpiadas), o ministro fala que, além de estádios, tudo isso visa a "unir o país e projetar uma imagem positiva para o mundo nos anos seguintes". Sim, quanto aos anos seguintes, podemos compreender sua esperança, quase otimismo. Porque, quanto a hoje, se é mesmo com a imagem que devemos nos preocupar, vamos muito mal. Gente que morre, violência contra turistas, estádios que desabam, dinheiro gasto sem transparência, monumento público dado de máo beijada, o que hão de pensar de nós lá fora? Mais importante: $o$ que devemos pensar de nós mesmos? (MÁXIMO, 2013, online ${ }^{60}$

Embora aborde a questáo da imagem no exterior (que ocupa a maior parte do artigo), o autor afirma que o crucial são as impressões que os brasileiros guardam de si mesmos. Houve outros casos em que a discussão relativa às impressóes causadas nos estrangeiros combinou-se com a afirmação de que o mais importante seria o país funcionar bem para os que nele vivem: 
O pior, ao meu ver, éo nosso sentimento de vergonha em relação aos "outros". O que a imprensa internacional vai dizer [...] Claro que isso depóe contra nosso pais, arranha nossa imagem e nos tira argumentos para dizer que somos um pais cada vez melhor. [...]

Não quero que os turistas tirem fotos do Estádio em Itaquera ou que achem bonita a obra em Recife. Quero que quem mora na zona leste tenha melhores condiçóes de ir e vir, e de habituar a região. O mesmo para as outras praças. Queria que a Copa durasse um mês para os turistas e uma vida para os brasileiros. ${ }^{61}$

Essa posição, contudo, mostrou-se minoritária. Na maioria das vezes, o foco foi a preocupação com a imagem externa, ou seja, com o que os estrangeiros iriam pensar, inclusive no âmbito futebolístico: o jogador holandês Seedorf, então atleta do Botafogo; e a seleção da Itália, que compareceu ao Engenhão para um treino para a Copa das Confederaçóes, sem saber que ele estava fechado. ${ }^{62}$

Houve quem apelasse para estereótipos relativos ao povo brasileiro, como a ideia de ser pouco ativo do ponto de vista político: "Brasil, um país anestesiado." ${ }^{63}$ Este argumento remete à ideia de fraqueza moral, outra das recorrências identificadas por Fico (1997) nas interpretaçôes intelectuais pessimistas sobre o país. Os problemas do Engenhão são revestidos de um significado mais amplo, que remete à crença em uma incompetência estrutural:

Mas infelizmente não tem jeito, aqui no Brasil é tudo feito nas coxas! Não se tem planejamento para nada. Dá-se um jeitinho aqui, outro acolá e assim vai... ${ }^{64}$

Tal como a citação que encerra a seção anterior, tais textos generalizam sobre uma suposta incapacidade de fazer as coisas direito inerente aos brasileiros, à administração do Estado e à política.

\section{Impactos para o Botafogo}

As discussões em torno dos impactos da interdição para o Botafogo podem ser agrupadas em cinco pontos. Primeiro, o possível prejuízo quanto ao desempenho do time:

Lamentável nesse bom momento do time dirigido por Oswaldo de Oliveira só mesmo a interdição do Engenhão — que impedirá que a equipe de General Severiano faça a festa e dê a volta olimpica em casa, caso confirme o favoritismo que, com justiça, passou a ostentar no Estadual. ${ }^{65}$

Em geral, os textos enfatizam que a equipe fazia uma boa campanha no campeonato estadual e lamentam que, justamente naquele momento, o estádio tenha sido interditado. $\mathrm{Na}$ ampla maioria dos casos, trata-se de artigos sobre jogos e/ou a campanha do clube, e não sobre a interdição. As mençôes à interdição aparecem como um fator que atrapalha ou pode atrapalhar o desempenho, do ponto de vista técnico. Após conquistar o título estadual, o Botafogo alcançou a liderança nas primeiras rodadas do Campeonato 
Brasileiro. A argumentação repetiu-se: um jornalista considerou "um crime que justamente nesse ótimo momento de sua equipe, o clube tenha ficado sem o Engenhão. O Glorioso deveria processar os (ir)responsáveis por este absurdo, exigindo reparação por perdas e danos." ${ }^{6}$

Segundo, o impacto sobre as finanças:

Há cinco anos, discutia-se como fazer o Engenhão ser superavitário. Logo depois de ganhar o processo de licitação e receber um estádio dado quase de presente pelo prefeito alvinegro César Maia, o Botafogo tinha custo mensal de administração. E só. No final de 2012, pela primeira vez o Botafogo falou claramente sobre superávit. O Morumbi foi deficitário entre sua inauguraçáo, em 1960, e o ano de 2003. Nos últimos anos, tem feito perto de R\$50 milhóes de lucro. Em 2012, o Botafogo lucrou mais de R\$ 20 milhöes, segundo matéria do jornal Extra. O Engenhão tornou-se uma das maiores fontes de receita do clube, inferior apenas aos cerca de $R \$ 60$ milhöes do novo contrato de televisão.

Essa longa citação coloca em contexto dois pontos importantes. Primeiro, as condiçôes - consideradas favoráveis pelos poucos que tocaram neste ponto - sob as quais o estádio foi cedido pela Prefeitura do Rio, aspecto ignorado na ampla maioria dos textos que abordam os prejuízos ao clube causados pela interdição. Segundo, é o único texto que apresenta dados para sustentar o argumento de que o estádio é uma fonte de receita importante. Uma das interpretaçóes possíveis para a comparação com o estádio do São Paulo Futebol Clube é a de que o Botafogo conseguiu obter lucro em relativamente poucos anos - o que, em parte, se explicaria por ter sido o estádio "dado quase de presente".

O texto prossegue detalhando as relaçôes econômicas que envolvem o Engenhão e que ligam o Botafogo a diferentes empresas: "Não é hora de abrir mão dessa receita. É tempo de resolver um problema gravíssimo. Como pagar os contratos assinados para exploração de camarotes? De espaços publicitários, como as cadeiras pintadas com o logotipo da Brahma? Não é simples." ${ }^{\prime 7}$ De acordo com o jornalista, as graves consequências financeiras são acompanhadas de outras em termos de gestão, contratos etc. Ele cita uma proposta e se contrapóe a ela:

A renúncia da empreiteira Delta a concluir a construção e a entrada do consórcio OASOdebrecht deixando claro que não teriam nada a ver com os dados produzidos no início do projeto deixaram o Botafogo sem pai nem mãe. É o que dizem os conselheiros alvinegros, principalmente os ligados ao ex-presidente Carlos Augusto Montenegro. Ninguém é pai da criança. Nem a Delta, nem a OAS, a Odebrecht ou a prefeitura.

Daí o ex-presidente Montenegro levantar a bandeira da devolução à prefeitura.

Não me parece o mais adequado. Do ponto de vista do Botafogo, o correto é exigir da prefeitura que cumpra sua parte no que foi assinado na licitação. Mas devolver o estádio justamente agora que dá lucro? Isso náo parece a medida mais inteligente. ${ }^{68}$ 
Ao debater o caminho que o clube deveria tomar para preservar seus direitos e minimizar os prejuízos, o texto apresenta duas possibilidades: a) devolução à Prefeitura; b) exigir da Prefeitura alguma contrapartida (na verdade, a matéria afirma que este é o ponto de vista de um setor das correntes políticas do clube, mas não explicita quais são os papéis atribuídos a cada parte no contrato, nem cita o documento.)

Houve textos que uniram os aspectos técnico e econômico: "O Botafogo não tem o Engenhão como estádio para mandar seus jogos e também gerar receitas que poderiam resolver parte das muitas dificuldades financeiras." ${ }^{69}$ Para certos jornalistas, os prejuízos financeiros poderiam de fato produzir impactos negativos sobre o desempenho:

O que pode atrapalhar o Glorioso daqui pra frente são os salários atrasados, que já fazem com que o time nem se concentre no Rio. Os sérios problemas financeiros do clube se agravaram com a interdição do Engenhão. [...] Seria uma lástima ver um elenco tão bom ser desfeito ou se desmotivar por falta de dinheiro. ${ }^{70}$

Terceiro, houve quem, explícita ou implicitamente, defendesse a ideia de que o estádio fora interditado por motivos políticos, com o objetivo de viabilizar a conclusão da privatização do Maracaná, que acabara de passar por uma reforma financiada com recursos públicos: "Que coincidência! Com essa infausta notícia sobre o Engenhão, o Consórcio que acaba de assumir o Maracanã fica com a faca e o queijo na mão para negociar com os clubes do Rio que não têm onde jogar (o Vasco é a exceção por ter São Januário)...”. ${ }^{11}$

De acordo com João Máximo, "ninguém explica por que fecharam o Engenhão, deixando a dupla Fla-Flu sem outra alternativa se não tornar-se cliente do novo estádio." $72 \mathrm{O}$ texto apresenta quatro frases consecutivas começando com "ninguém explica". A expressão carrega um sentido ambíguo. Pode-se interpretá-la literalmente: nenhuma pessoa veio a público apresentar explicaçóes para os acontecimentos e decisóes criticados pelo autor. Mas também pode ser interpretada em outro sentido: o de que não existe explicação (ninguém explica, nem poderia explicar). Acreditamos que a primeira alternativa pode ser problematizada a partir de uma reflexão sobre as rotinas produtivas: como explicar que "ninguém explica"? Será que, nas entrevistas coletivas, os repórteres que cobrem futebol perguntam sobre tais assuntos? Será que eles buscam estas informaçôes? Será que existe espaço e incentivo editorial para que o façam? Será que as reunióes de pauta, onde se decide que acontecimentos futuros receberão atenção jornalística, abrem espaço para tais temas? ${ }^{73}$

Longe de buscarmos uma conclusão, lançamos estas questôes para apontar lacunas nos estudos sobre esporte na Comunicação, particularmente no caso do futebol, que vem recebendo a maior parte da atenção dos pesquisadores (Fortes, 2011, 2014). Enquanto vários estudos focam temáticas parecidas e chegam a conclusóes semelhantes, numerosas questóes relevantes para melhorarmos e complexificarmos nossa compreensão e análise da construção 
esportiva na mídia continuam intocadas pelos pesquisadores. A análise de rotinas produtivas, caminho para responder as questóes acima, é uma delas.

Quarto, houve mençôes às correntes internas da política do clube, como enunciado na citação longa que menciona um ex-presidente como fonte. ${ }^{74}$ Outros textos fazem o mesmo: “'O Botafogo é passageiro desse trem-fantasma chamado 'fechamento do Engenhão" - Carlos Eduardo Pereira, líder do grupo Mais Botafogo, criticando a inação da diretoria diante da Prefeitura do Rio." ${ }^{25}$ O blogue De Prima trouxe colunas com seguidas mençôes a nomes e iniciativas do grupo citado, que fazia oposição ao então presidente do Botafogo, Maurício Assumpção. As relaçóes entre jornalistas e seus informantes - fontes, no jargão das redações - são um aspecto crucial da elaboração das notícias, mas raramente discutido nos estudos de Comunicação que enfatizam o esporte.

Quinto, propostas de trocar o nome do estádio. Boa parte delas justificava a retirada do nome de João Havelange devido a denúncias de corrupção - que tiveram grande repercussão midiática à época em que os textos foram escritos - e que o levaram a renunciar a cargos que ocupava em entidades internacionais.

Depois do que foi revelado, faz sentido o Engenhão continuar a se chamar Estádio João Havelange? Apoio o movimento para que se mude seu nome para João Saldanha ou Nílton Santos (já que Mané Garrincha é nome de estádio em Brasilia). Já! (PRADO, Estrelas também choram, 2013, online) ${ }^{76}$

Destacam-se, portanto, duas linhas convergentes de argumentação: por um lado, retirar o nome de Havelange, que não faria jus à homenagem. Por outro, colocar o de alguém que a merecesse, tanto pelas realizaçóes no futebol quanto pelo vínculo histórico com o Botafogo. ${ }^{77}$ Essa proposta de troca iria ao encontro de um conjunto de medidas empreendidas pelo clube na tentativa de criar laços identitários com o novo estádio, como a colocação, nas entradas, de estátuas de seus principais ídolos (Curi, 2012)

\section{Considerações finais}

Neste artigo, analisamos a discussão sobre o fechamento do Engenhão pela Prefeitura do Rio de Janeiro em blogues vinculados a grandes empresas de comunicação. Diferentes pontos de vista e temas foram mobilizados pelos jornalistas para narrar, explicar e, principalmente, criticar o acontecimento. Eles lançaram mão de distintas formas de contextualização para apresentar possíveis causas e consequências da medida, além de discutir as responsabilidades pelo ato e pela situação anterior (às vezes remetendo ao período da construção, bem como a discursos de dirigentes políticos e esportivos justificando a candidatura da cidade e do país a sediar eventos esportivos); o cenário macro de candidatura, organização e realização de megaeventos esportivos na cidade e no país; os problemas da administração estatal e das entidades esportivas, bem como a maneira negativa com que os dirigentes 
destas instituições muitas vezes são vistos pela população; a imagem do Brasil no cenário internacional; as relaçôes entre empreiteiras e poder público; os impactos para o clube e o time do Botafogo, bem como a reação de seus dirigentes e torcedores.

De forma geral, as falas encontradas pareceram demonstrar revolta, mas não surpresa diante da interdição. A maioria fica entre duas possibilidades: a) são contundentes, mas não apresentam (nem parecem buscar) informações básicas que permitam ao leitor compreender de forma clara as relaçóes que estão sendo criticadas; b) se limitam a fazer insinuaçóes e perguntas (para as quais, como argumentamos, dificilmente o próprio jornalista buscará respostas).

Consideramos importante retomar o dado de que não encontramos referências ao assunto na maioria dos blogues lidos. Diversas razóes podem explicar tal situação (ver nota 11). Não obstante, um possível motivo reside nas próprias características da abordagem do esporte nos veículos de comunicação hegemônicos. Discutindo a cobertura nos EUA, McChesney (1989) afirma que o esporte é um tema que cai bem na mídia comercial porque frequentemente é abordado sem se discutir aspectos como política, corrupção e doping, o que combina com os interesses de uma mídia que quer vender a todos e se pretende, entre outras características, apartidária e comprometida com a objetividade. Gruneau (1989) afirma que, na cultura profissional do jornalismo na América do Norte, problemas e conflitos são considerados importantes notícias. Contudo, no noticiário esportivo é diferente. A ênfase é colocada na ocorrência regular de eventos e no inerente caráter positivo dos mesmos. Neste sentido, qualquer atividade que atrapalhe o curso dos eventos é tida como negativa: boicotes, acidentes, greves, intervençôes políticas ou religiosas, fenômenos meteorológicos etc. (p. 146). Até onde sabemos, ainda estão por se fazer estudos que explorem tais aspectos no Brasil. ${ }^{78}$

Além desta e das sugestôes de pesquisa apontadas ao longo do artigo, apresentamos uma última: investigar, no mesmo recorte temporal, a cobertura esportiva (reportagens) dos sites dos veículos de comunicação aos quais os blogues aqui analisados estão vinculados; e também o universo de blogues de torcedores do Botafogo. Aliás, alguns blogues de torcedores realizaram uma cobertura constante sobre o assunto, narrando e debatendo cada etapa do processo que se desenrolou no período que analisamos. Essa cobertura, via de regra, traz mais informaçóes do que os textos de jornalistas, em alguns casos acompanhada de imagens e links para os relatórios e documentos oficiais. Portanto, reside aí um objeto rico para investigaçóes futuras do esporte na Comunicação, com o potencial de ampliar o foco dos estudos sobre torcidas e torcedores para além das torcidas organizadas, objeto de repetidos (e muitas vezes repetitivos) trabalhos. ${ }^{79}$

Por fim, mencionamos dois pontos que podem ser úteis em investigaçôes futuras, mas não foram mencionados ao longo do artigo. Primeiro, o componente de gênero do universo pesquisado: praticamente inexistem 
blogueiras escrevendo sobre futebol. Segundo, o pouco uso de imagens pelos blogues. Em geral, as imagens são fotos de jogadores (comemorando gols, principalmente) ou desenhos de esquemas táticos. Como era de se esperar, houve algumas fotografias do Engenhão, de cunho ilustrativo: frequentemente não receberam crédito, nem foram mencionadas no texto.

\section{Referências bibliográficas}

ALBUQUERQUE, Afonso de. A obrigatoriedade do diploma e a identidade jornalística no Brasil: um olhar pelas margens. Contracampo, Niterói, n. 14, p. 73-91, 2006.

ALBUQUERQUE, Afonso de; SOARES, Rafael Fortes. Notícias de Notícias: Notícias do Planalto, memória e autoridade jornalística. Comunicação \& Política, Rio de Janeiro, nova série, v. XI, n. 1, p. 13569, jan.-abr. 2004.

ALMEIDA, Bárbara Schausteck; MARCHI JUNIOR, Wanderley. O Brasil e os megaeventos esportivos: os subsídios da política externa. Motrivivência, v. 6, n. 42, p. 13-26, jun. 2014.

AMARAL, Adriana; RECUERO, Raquel; MONTARDO, Sandra (org.). Blogs.com: estudos sobre blogs e comunicação. São Paulo: Momento Editorial, 2009a.

AMARAL, Adriana; RECUERO, Raquel; MONTARDO, Sandra Portella. Blogs: mapeando um objeto. In: AMARAL, Adriana; RECUERO, Raquel; MONTARDO, Sandra (org.). Blogs.com: estudos sobre blogs e comunicação. São Paulo: Momento Editorial, 2009b. p. 27-53.

AMORIM, Celso. Teerã, Ramalá e Doha: memórias da política externa ativa e altiva. São Paulo: Benvirá, 2015.

BOOTH, Douglas. Olympic city bidding: An exegesis of power. International Review for the Sociology of Sport, v. 46, n. 4, p. 367-386, December 2011. (Ahead of print, p. 1-20, May 19, 2011)

CURI, Martin. Espaços de emoção: Torcedores nos estádios. In: Encontro Anual da ANPOCS, 36, 2012. Águas de Lindóia, SP. Anais... 2012.

CURI, Martin; KNIJNIK, Jorge; MASCARENHAS, Gilmar. The Pan American Games in Rio de Janeiro 2007: Consequences of a sport mega-event on a BRIC country. International Review for the Sociology of Sport, v. 46, n. 2, p. 140-156, 2011.

DAMO, Arlei Sander; OLIVEN, Ruben George. O Brasil no horizonte dos megaeventos esportivos de 2014 e 2016: sua cara, seus sócios e seus negócios. Horizontes Antropológicos, Porto Alegre, ano 19, n. 40, p. 19-63, jul.-dez. 2013.

ESCOBAR, Juliana Lúcia. Blogs como nova categoria de webjornalismo. In: AMARAL, Adriana; RECUERO, Raquel; MONTARDO, Sandra (org.). Blogs.com: estudos sobre blogs e comunicação. São Paulo: Momento Editorial, 2009. p. 217-235. 
FICO, Carlos. Reiventando o otimismo: ditadura, propaganda e imaginário social no Brasil. Rio de Janeiro: Editora Fundação Getúlio Vargas, 1997.

FORTES, Rafael. Estudos de esporte na área de comunicação: um panorama e algumas propostas. Revista FAMECOS, v. 18, n. 2, mai-ago 2011, p. 598-614.

FORTES, Rafael. O Mundial de 2014 no imaginário popular brasileiro. In: MARQUES, José Carlos (org.). A Copa das copas?: reflexóes sobre o Mundial de futebol de 2014 no Brasil. São Paulo: Ludens São Paulo, 2015. p. 39-56.

FORTES, Rafael. Um balanço dos estudos de esporte no Congresso Brasileiro de Ciências da Comunicação de 2012. Contracampo, Niterói, vol. 30, n. 2, p. 83-100, ago.-nov. 2014.

FORTES, Rafael; ALBUQUERQUE, Afonso de. O jornalismo e a obrigatoriedade do diploma: negociando as fronteiras da comunidade jornalística no Brasil. Comunicação e Sociedade, Braga, vol. 9-10, p. 169-188, 2006.

GIRGINOV, Vassil. Governance of the London 2012 Olympic Games legacy. Internacional Review for the Sociology of Sport, v. 47, n. 5, p. 543558, Oct. 2012.

GRUNEAU, Richard. Making Spectacle: A Case Study in Television Sports Production. In: WENNER, Lawrence (ed.). Media, Sports \& Society. Newbury Park: Sage, 1989. p. 134-154.

JAGO, Leo et al. Optimising the potential of mega-events: an overview. International Journal of Event and Festival Management, v. 1, n. 3, p. 220-237, 2010.

JENNINGS, Andrew. Investigating corruption in corporate sport: The IOC and FIFA. International Review for the Sociology of Sport, v. 46, n. 4, p. 387-398, December 2011. (Ahead of print, p. 1-12, May 19, 2011).

MASCARENHAS, Gilmar. Globalização e espetáculo: o Brasil dos megaeventos esportivos. In: PRIORE, Mary del; MELO, Victor Andrade de (org.). História do esporte no Brasil: do Império aos dias atuais. São Paulo: Ed. UNESP, 2009. p. 505-533.

MCCHESNEY, Robert W. Media Made Sport: A History of Sports Coverage in the United States. In: WENNER, Lawrence (ed.). Media, Sports \& Society. Newbury Park: Sage, 1989. p. 49-69.

PAMPUCH, Marcelo; ALMEIDA, Bárbara Schausteck de; MARCHI JUNIOR, Wanderley. Os legados estruturais dos Jogos Olímpicos (1992-2008): uma revisão de literatura. Cadernos da Escola de Educação e Humanidades, v. 1, n. 7, 2012.

QUADROS, Claudia Irene de; SPONHOLZ, Liriam. Deu no blog jornalístico: é notícia? Intexto, Porto Alegre, v. 2, n. 15, p. 1-14, jul.-dez. 2006. 
RUBIO, Katia. Postulaçôes brasileiras aos Jogos Olímpicos: consideraçóes acerca da lenda do distanciamento entre política e Movimento Olímpico. Revista Bibliográfica de Geografia y Ciencias Sociales, v. XV, n. 895 (10), 5 de noviembre de 2010.

VIGEVANI, Tullo; CEPALUNI, Gabriel. A política externa de Lula da Silva: a estratégia da autonomia pela diversificaçáo. Contexto Internacional, Rio de Janeiro, v. 29, n. 2, p. 273-335, jul.-dez. 2007.

VIMIEIRO, Ana Carolina. A produtividade digital dos torcedores de futebol brasileiros: formatos, motivaçóes e abordagens. Revista Contracampo, Niterói, v. 31, n. 1 , p. 23-59, dez.-mar. 2014.

\section{Notas}

1. O apelido deve-se à localização do estádio, situado no bairro Engenho de Dentro. Em fevereiro de 2015, a Prefeitura "autorizou o Botafogo a chamar o Estádio Olímpico Joáo Havelange de Estádio Nilton Santos". No período correspondente ao recorte temporal do corpus, vigorava a primeira denominação, que continua sendo o nome oficial. EDUARDO Paes autoriza o Botafogo a chamar Engenhão de Estádio Nilton Santos. Lancenet, 10 fev. 2015. Disponível em: <http://www.lancenet.com. br/botafogo/Eduardo-Botafogo-Engenhao-Estadio-Nilton_0_1301269984.html>. Acesso em 16 mar. 2015.

2. Para uma detalhada narrativa memorialística, ver Amorim (2015).

3. Na lista elaborada por Booth (2011) com as cidades candidatas a sede dos jogos de 1976 em diante, aparecem Brasília (2000) e Rio de Janeiro (2004, 2012 e 2016).

4. Para Mascarenhas (2009), "o Pan 2007 produziu (...) instalaçóes esportivas de excelente nível, porém destinadas ao abandono" (p. 527) e seu planejamento foi caracterizado por "falta de transparência" e "autoritarismo", além de haver consumido "3,4 bilhôes de reais, o que representa oito vezes mais do que o inicialmente previsto, quando da candidatura da cidade em 2002” (p. 524).

5. Tais debates também ocorrem no cenário internacional. Para exemplos de investigaçôes críticas no plano científico e no jornalístico, ver, respectivamente, Booth (2011) e Jennings (2011). Os dois artigos contém prólogos descrevendo censura política sofrida por uma revista científica, que decidiu não publicá-los.

6. CARDOSO, Cristiane. Prefeitura do Rio decreta início imediato de obras do Engenhão. G1, 10 jun. 2013. Disponível em: <http://g1.globo.com/rio-de-janeiro/ noticia/2013/06/prefeitura-do-rio-decreta-inicio-imediato-de-obras-do-engenhao. html>. Acesso em 8 jan. 2015.

7. De forma complementar, realizamos levantamento em cinco blogues de torcedores botafoguenses.

8. Mesmo assim, diversos blogues foram excluídos, como aqueles que se dedicavam exclusivamente ao futebol praticado em outros países e continentes. A pesquisa tem uma série de armadilhas, referentes às idiossincrasias da organizaçáo da informação na internet: no site da ESPN, por exemplo, a lista de blogues do menu superior é diferente da disponível no menu do lado direito. Em cada blogue, fizemos o levantamento através de leitura da listagem de textos (browse) entrada a entrada, por ordem cronológica de postagem, sem depender de mecanismo de busca. Os 
mecanismos de busca foram usados apenas nos casos em que inexistia a opção de browse, como nos blogues das rádios $\mathrm{CBN}$ e Tupi.

9. Parte dos blogues do UOL acabou incluída porque os jornalistas trabalham em emissoras ou veículos cujos sites constavam da amostragem (por exemplo, Juca Kfouri).

10. Isto no que diz respeito ao universo específico que investigamos. Evidentemente, os comentários de leitores deixados em sites de notícias e blogues podem constituir rico corpus para análise.

11. Verificar individualmente cada blogue em função de determinadas características, tal como propõe Escobar (2009), para, em tese, determinar seu caráter jornalístico ou não-jornalístico escapa ao propósito de nossa pesquisa.

12. Considerando-se a divisão formal que orienta os espaços noticiosos na ampla maioria dos veículos e produtos de comunicação brasileiros, supostamente separando informação e opinião.

13. PRADO, Renato Maurício. Gigantes ou anões. O blog do Renato Maurício Prado, 02 abr. 2013. Disponível em: <http://oglobo.globo.com/esportes/rmp/ posts/2013/04/02/gigantes-ou-anoes-491855.asp>. Acesso em 29 mai. 2014.

14. MALIA, José Roberto. Engenhão, R \$ 380 mi: uma vergonha da pátria de chuteiras. E todos estâo soltos! José Roberto Malia. 7 jun. 2013. Disponível em $<$ http://espn. uol.com.br/post/334934_engenhao-r-380-mi-mais-uma-vergonha-da-patria-dechuteiras-e-todos-estao-soltos>. Acesso em 16 jun. 2014.

15. CoRio é o Comitê Organizador Rio 2016. KFOURI, Juca. Parabéns, Brasil olímpico! Blog do Juca Kfouri, 27 mar. 2013. Disponível em: http://blogdojuca.uol. com.br/2013/03/parabens-brasil-olimpico/. Acesso em 01 ago. 2014.

16. A discussão sobre legados é extensa e controversa. Para uma categorização dos possíveis legados positivos e negativos e uma discussáo do assunto, ver os textos citados.

17. PRADO, Renato Maurício. Gigantes ou anôes. O blog do Renato Maurício Prado, 02 abr. 2013. Disponível em: http://oglobo.globo.com/esportes/rmp/posts/2013/04/02/ gigantes-ou-anoes-491855.asp. Acesso em 29 mai. 2014.

18. PENIDO, Luiz. Engenhão interditado vira mar de dúvidas. Fala, Penido! O Garotão da Galera, 26 mar 2013. Disponível em: <http://colunas.radioglobo. globoradio.globo.com/luiz-penido/platb/2013/03/26/engenhao-interditado-viramar-de-duvidas>. Acesso em 21 jun. 2014.

19. CALÇADE, Paulo. Estádios da Copa podem repetir o fiasco do Engenhão. Blog de Paulo Calçade, 2 abr. 2013. Disponível em: <http://espn.uol.com.br/post/320441_ estadios-da-copa-podem-repetir-fiasco-do-engenhao >. Acesso em 31 jul. 2014.

20. BECHLER, Marcelo. Que vergonha do Engenhão. Blog do Bechler. 28 mar. 2013. Disponível em: <http://colunas.radioglobo.globoradio.globo.com/platb/ marcelobechler/2013/03>. Acesso em 21 jun. 2014.

21. JANCA. A interdição do Engenhão. Bastidores - Copa e Olimpiada, 27 mar. 2013. Disponível em: http://blogs.lancenet.com.br/blogdojanca/2013/03/27/a-interdicaodo-engenhao/. Acesso em 22 mai. 2014.

22. CASTELLAR, Michel. COI, Maracanã e Engenhão. Rio 2016, 30 abr. 2013. Disponível em: http://blogs.lancenet.com.br/rio2016/2013/04/30/coi-maracana-eengenhao/. Acesso em 29 mai. 2014. Este blogue foi o único a priorizar a discussão 
sobre a preparação para os Jogos Olímpicos, abordando, em outros três textos, a relação entre o conserto da cobertura e as obras para 2016.

23. PUGLIESE, Sérgio. Engenhão em tempos de glória. A pelada como ela é, 28 mar. 2013. Disponível em: http://oglobo.globo.com/blogs/pelada/posts/2013/03/28/ engenhao-em-tempos-de-gloria-491363.asp. Acesso em 11 jun. 2014.

24. MÁXIMO, João. O tal legado que tanto nos orgulha. Blog de João Máximo, 16 abr. 2013. Disponível em: < http://espn.uol.com.br/post/323301_o-tal-legado-quetanto-nos-orgulha>. Acesso em 31 jul. 2014.

25. Muitos jogos, inclusive as semifinais e final do campeonato, foram transferidos para o Estádio Raulino de Oliveira, em Volta Redonda. PENIDO, Luiz. Engenhão interditado vira mar de dúvidas. Fala, Penido! O Garotão da Galera, 26 mar 2013. Disponível em: <http://colunas.radioglobo.globoradio.globo.com/luiz-penido/platb/2013/03/26/ engenhao-interditado-vira-mar-de-duvidas>. Acesso em 21 jun. 2014.

26. BENJA. Imaginem o que virá pela frente. Papo com Benja, 27 mar. 2013. Disponível em: http://blogs.lancenet.com.br/benja/2013/03/27/imaginem-o-que-vira-pelafrente/. Acesso em 29 mai. 2014.

27. Para aprofundar a investigação, seria necessário explorar as condiçôes de produção dos blogues, conforme dito no item anterior.

28. ROCHA, André. Botafogo: campeão incontestável do Rio e pronto para o salto nacional. Olho Tático, 5 jun. 2013. Disponível em: <http://espn.uol.com. br/post/327560_botafogo-campeao-incontestavel-no-rio-e-pronto-para-o-saltonacional>. Acesso em 27 jul. 2014.

29. O Aterro do Flamengo abrange o maior parque do município, tem vários campos de futebol e é um local tradicional de peladas e de campeonatos amadores, inclusive de trabalhadores de bares e restaurantes. Porcão e Belmonte são, respectivamente, redes de churrascarias e de bares e contam com unidades próximas ao Aterro. "Rubinho" é Rubens Lopes da Costa Filho, presidente da Federação de Futebol do Estado do Rio de Janeiro. PRADO, Renato Maurício. E o vento levou... O blog do Renato Mauricio Prado, 29 mar. 2013. Disponível em: http://oglobo.globo.com/esportes/ rmp/posts/2013/03/29/e-vento-levou-491501.asp. Acesso em 29 mai. 2014.

30. KFOURI, André. Camisa 12. Blog dos colunistas, 29 mar. 2013. Disponível em: http://blogs.lancenet.com.br/andrekfouri/2013/03/29/camisa-12-137/. Acesso em 22 mai. 2014.

31. JANCA. Cariocas itinerantes. Bastidores - Copa e Olimpiada, 13 abr. 2013. Disponível em: http://blogs.lancenet.com.br/blogdojanca/2013/04/13/cariocasitinerantes/. Acesso em 22 mai. 2014.

32. CASTRO, Lúcio de. Odorico, Paes, Cabral, Nuzman, o estádio que honra o nome e um documentário definitivo. Blog de Lúcio de Castro, 26 mar. 2013. Disponível em: <http://espn.uol.com.br/post/319097_odorico-paes-cabral-nuzman-o-estadioque-honra-o-nome-e-um-documentario-definitivo>. Acesso em 31 jul. 2014. Esta deslegitimação dos críticos dos megaeventos esportivos, em alguma medida, também pode ser observada em certos espaços e debates científicos.

33. Na visão do autor, sem que houvesse contrapartida da população. JANCA. Pra frente Brasil. Bastidores - Copa e Olimpiada, 09 jun. 2013. Disponível em: http://blogs. lancenet.com.br/blogdojanca/2013/06/09/pra-frente-brasil/. Acesso em 22 mai. 2014. 
34. O material empírico pesquisado, em parte, foi escrito nos dias antecedentes e durante a Copa das Confederaçóes (realizada entre 15 e 30/6/2013). Durante o período, discutiu-se bastante a infraestrutura do país, com foco não apenas naquela competição, mas na Copa do Mundo (que seria disputada um ano depois) e nos Jogos Olímpicos (2016). O Campeonato Brasileiro foi suspenso e a cobertura dos clubes - e do futebol do Rio de Janeiro - diminuiu bastante.

35. PRADO, Renato Maurício. Vergonhão (2 clichê). O blog do Renato Maurício Prado, 09 jun. 2013. Disponível em: http://oglobo.globo.com/esportes/rmp/ posts/2013/06/09/vergonhao-2-cliche-499541.asp. Acesso em 29 mai. 2014.

36. Praticamente todos mencionaram os mesmos valores, embora nenhum cite a fonte das informações.

37. O campeonato teve doze cidades-sede. No caso de São Paulo, não foi possível comparar as estimativas da Arena Corinthians, visto que em 2009 esperava-se que o Morumbi recebesse os jogos. A Arena Amazonas foi a única cuja estimativa de 2013 - 415 milhóes de reais - era inferior à de 2009 - 500 milhóes.

38. JANCA. Pra frente Brasil. Bastidores - Copa e Olimpiada, 09 jun. 2013. Disponível em: http://blogs.lancenet.com.br/blogdojanca/2013/06/09/pra-frente-brasil/. Acesso em 22 mai. 2014. Sobre o assunto, ver: FONSECA, Bruno et al. Tem dinheiro público, sim, senhor. Pública, 10 jun. 2014. Disponível em: <http://apublica.org/2014/06/ tem-dinheiro-publico-sim-senhor>. Acesso em 20 jan. 2015.

39. PRADO, Renato Maurício. Era só o que faltava. O blog do Renato Maurício Prado, 26 mar. 2013. Disponível em: http://oglobo.globo.com/esportes/rmp/ posts/2013/03/26/era-so-que-faltava-491249.asp. Acesso em 29 mai. 2014.

40. Ambos com décadas de profissão e tendo ocupado cargos de chefia em distintos veículos.

41. PENIDO, Luiz. Engenhão interditado vira mar de dúvidas. Fala, Penido! O Garotão da Galera, 26 mar 2013. Disponível em: <http://colunas.radioglobo. globoradio.globo.com/luiz-penido/platb/2013/03/26/engenhao-interditado-viramar-de-duvidas>. Acesso em 21 jun. 2014.

42. Os textos do blogue de Prado muitas vezes são reproduçóes de sua coluna no diário $O$ Globo.

43. BECHLER, Marcelo. Que vergonha do Engenhão. Blog do Bechler. 28 mar. 2013. Disponível em: <http://colunas.radioglobo.globoradio.globo.com/platb/ marcelobechler/2013/03>. Acesso em 21 jun. 2014.

44. KFOURI, André. Camisa 12. Blog dos colunistas, 29 mar. 2013. Disponível em: http://blogs.lancenet.com.br/andrekfouri/2013/03/29/camisa-12-137/. Acesso em 22 mai. 2014.

45. PRADO, Renato Maurício. Gigantes ou anóes. O blog do Renato Maurício Prado, 02 abr. 2013. Disponível em: http://oglobo.globo.com/esportes/rmp/posts/2013/04/02/ gigantes-ou-anoes-491855.asp. Acesso em 29 mai. 2014.

46. COELHO, Paulo Vinícius. A irresponsabilidade no caso Engenhão é fácil de localizar. A Delta não tem nada a ver com isso? Blog de Paulo Vinícius Coelho, 27 mar. 2013. Disponível em: <http://espn.uol.com.br/post/319120_a-irresponsabilidade-no-caso-engenhao-e-facilde-localizar-a-delta-nao-tem-nada-a-ver-com-isso>. Acesso em 30 jul. 2014.

47. Outra ocorrência rara no corpus: citar uma fonte (com link) de um veículo de comunicação

- Carta Capital - que não pertence à empresa/grupo em que o jornalista trabalha. 
48. COELHO, Paulo Vinícius. A irresponsabilidade no caso Engenhão é fácil de localizar. A Delta não tem nada a ver com isso? Blog de Paulo Vinícius Coelho, 27 mar. 2013. Disponível em: <http://espn.uol.com.br/post/319120_a-irresponsabilidadeno-caso-engenhao-e-facil-de-localizar-a-delta-nao-tem-nada-a-ver-com-isso $>$. Acesso em 30 jul. 2014.

49. MALIA, José Roberto. Engenhão, R \$ 380 mi: uma vergonha da pátria de chuteiras. E todos estão soltos! José Roberto Malia. 7 jun. 2013. Disponível em $<$ http://espn. uol.com.br/post/334934_engenhao-r-380-mi-mais-uma-vergonha-da-patria-dechuteiras-e-todos-estao-soltos>. Acesso em 16 jun. 2014.

50. PENIDO, Luiz. Engenhão interditado vira mar de dúvidas. Fala, Penido! O Garotão da Galera, 26 mar 2013. Disponível em: <http://colunas.radioglobo. globoradio.globo.com/luiz-penido/platb/2013/03/26/engenhao-interditado-viramar-de-duvidas>. Acesso em 21 jun. 2014.

51. CASTELLAR, Michel. A cobertura do Engenhão. Rio 2016, 30 mar. 2013. Disponível em: http://blogs.lancenet.com.br/rio2016/2013/03/30/a-cobertura-doengenhao/. Acesso em 29 mai. 2014.

52. CASTRO, Lúcio de. Odorico, Paes, Cabral, Nuzman, o estádio que honra o nome e um documentário definitivo. Blog de Lúcio de Castro, 26 mar. 2013. Disponível em: $<$ http://espn.uol.com.br/post/319097_odorico-paes-cabral-nuzman-o-estadio-quehonra-o-nome-e-um-documentario-definitivo>. Acesso em 31 jul. 2014.

53. Estes posicionamentos apareceram em alguns blogues jornalísticos e, com maior frequência, nos blogues de torcedores botafoguenses.

54. HABIB, Lucas. A diferenXa. Aliança Alvinegra, 7 mai. 2013. Disponível em: <http://www.aliancaalvinegra.com/2013/05/a-diferenxa-2>. Acesso em 4 ago. 2014. Também mencionado em: ARAÚJO, Caio. Notícias do vento. Bate-bola alvinegro, 06 mai. 2013. Disponível em: http://globoesporte.globo.com/rj/torcedor-botafogo/ platb/2013/05/06/noticias-do-vento/. Acesso em 20 mai. 2014.

55. BETING, Mauro. Engenheiráo. Blog dos colunistas, 27 mar. 2013. Disponível em: http:// blogs.lancenet.com.br/maurobeting/2013/03/27/engenheirao/. Acesso em 21 mai. 2014.

56. KFOURI, André. Camisa 12. Blog dos colunistas, 29 mar. 2013. Disponível em: http:// blogs.lancenet.com.br/andrekfouri/2013/03/29/camisa-12-137/. Acesso em 22 mai. 2014.

57. PRADO, Renato Maurício. E o vento levou... O blog do Renato Maurício Prado, 29 mar. 2013. Disponível em: http://oglobo.globo.com/esportes/rmp/posts/2013/03/29/ e-vento-levou-491501.asp. Acesso em 29 mai. 2014.

58. Para um esforço de articular os argumentos de Fico com os discursos em torno da Copa do Mundo de 2014, ver Fortes (2015).

59. MÁXIMO, João. O tal legado que tanto nos orgulha. Blog de João Máximo, 16 abr. 2013. Disponível em: < http://espn.uol.com.br/post/323301_o-tal-legado-quetanto-nos-orgulha>. Acesso em 31 jul. 2014.

60. MÁXIMO, João. O tal legado que tanto nos orgulha. Blog de João Máximo, 16 abr. 2013. Disponível em: < http://espn.uol.com.br/post/323301_o-tal-legado-quetanto-nos-orgulha>. Acesso em 31 jul. 2014.

61. BECHLER, Marcelo. Que vergonha do Engenhão. Blog do Bechler. 28 mar. 2013. Disponível em: <http://colunas.radioglobo.globoradio.globo.com/platb/ marcelobechler/2013/03>. Acesso em 21 jun. 2014. 
62. BENJA. Imaginem o que virá pela frente. Papo com Benja, 27 mar. 2013. Disponível em: http://blogs.lancenet.com.br/benja/2013/03/27/imaginem-o-que-vira-pelafrentel. Acesso em 29 mai. 2014. KFOURI, Juca. Os italianos estão bravos. Blog do Juca Kfouri, 13 jun. 2013. Disponível em: http://blogdojuca.uol.com.br/2013/06/ os-italianos-estao-bravos/. Acesso em 01 ago. 2014.

63. MALIA, José Roberto. Engenhão, R \$ 380 mi: uma vergonha da pátria de chuteiras. E todos estão soltos! José Roberto Malia. 7 jun. 2013. Disponível em <http://espn. uol.com.br/post/334934_engenhao-r-380-mi-mais-uma-vergonha-da-patria-dechuteiras-e-todos-estao-soltos>. Acesso em 16 jun. 2014.

64. BENJA. Imaginem o que virá pela frente. Papo com Benja, 27 mar. 2013. Disponível em: http://blogs.lancenet.com.br/benja/2013/03/27/imaginem-o-que-vira-pelafrente/. Acesso em 29 mai. 2014.

65. PRADO, Renato Maurício. A estrela sobre. E brilha! O blog do Renato Maurício Prado, 05 abr. 2013. Disponível em: http://oglobo.globo.com/esportes/rmp/ posts/2013/04/05/a-estrela-sobe-brilha-492226.asp. Acesso em 29 mai. 2014.

66. PRADO, Renato Maurício. Vergonhão (2 clichê). O blog do Renato Maurício Prado, 09 jun. 2013. Disponível em: http://oglobo.globo.com/esportes/rmp/ posts/2013/06/09/vergonhao-2-cliche-499541.asp. Acesso em 29 mai. 2014.

67. COELHO, Paulo Vinícius. Melhor cenário para o Botagofo não é entregar o Engenhão, mas cobrar seus danos da Prefeitura. Blog de Paulo Vinícius Coelho, 2 abr. 2013. Disponível em: <http://espn.uol.com.br/post/320217_melhor-cenario-para-obotafogo-nao-e-entregar-engenhao-mas-cobrar-seus-danos-da-prefeitura $>$. Acesso em 30 jul. 2014.

68. COELHO, Paulo Vinícius. Melhor cenário para o Botagofo não é entregar o Engenhão, mas cobrar seus danos da Prefeitura. Blog de Paulo Vinícius Coelho, 2 abr. 2013. Disponível em: <http://espn.uol.com.br/post/320217_melhor-cenario-para-o-botafogonao-e-entregar-engenhao-mas-cobrar-seus-danos-da-prefeitura>. Acesso em 30 jul. 2014.

69. ROCHA, André. É preciso exaltar o Botafogo como se não houvesse amanhã. Olho Tático, 1 jun. 2013. Disponível em: <http://espn.uol.com.br/post/333588_e-precisoexaltar-o-botafogo-como-se-nao-houvesse-amanha>. Acesso em 27 jul. 2014.

70. PRADO, Renato Maurício. Dedo na ferida. O blog do Renato Maurício Prado, 12 abr. 2013. Disponível em: http://oglobo.globo.com/esportes/rmp/posts/2013/04/12/ dedo-na-ferida-493096.asp. Acesso em 29 mai. 2014.

71. PRADO, Renato Maurício. Vergonhão (2 clichê). O blog do Renato Maurício Prado, 09 jun. 2013. Disponível em: http://oglobo.globo.com/esportes/rmp/ posts/2013/06/09/vergonhao-2-cliche-499541.asp. Acesso em 29 mai. 2014. Se, eventualmente, nos blogues de jornalistas essa vantagem é mencionada, em blogues de torcedores ela é convertida em argumento para questionar a validade do laudo que indicou a interdição. Aliás, a crítica mais pormenorizada ao laudo da comissão designada pela Prefeitura está em um blogue de torcedor. Nenhum blogue pesquisado realizou uma análise extensa do laudo. FIGUEIRA, Guilherme. Para quem gosta de ter minhoca na cabeça. Aliança Alvinegra, 12 abr. 2013. Disponível em: <http://www. aliancaalvinegra.com/2013/04/para-quem-gosta-de-ter-minhoca-na-cabeca $>$. Acesso em 4 ago. 2014. FIGUEIRA, Guilherme. Piada pronta. Aliança Alvinegra, 12 jun. 2013. Disponível em: <http://www.aliancaalvinegra.com/2013/06/piada-pronta-2>. Acesso em 4 ago. 2014. 
72. MÁXIMO, João. Ainda o Maracanã, o velho e o novo. Blog de João Máximo, 3 jun. 2013. Disponível em: <http://espn.uol.com.br/post/334004_ainda-o-maracanao-velho-e-o-novo>. Acesso em 31 jul. 2014.

73. O fechamento teve impactos para o bairro Engenho de Dentro (comércio, fonte de renda e trabalho para moradores, segurança pública etc.). O fato de tais impactos serem ignorados no material que pesquisamos pode dizer algo sobre a visão hegemônica, nas redaçôes, a respeito da cidade e, particularmente, da Zona Norte. Agradecemos a André Alexandre Guimarães Couto por esta observação.

74. COELHO, Paulo Vinícius. Melhor cenário para o Botagofo não é entregar o Engenhão, mas cobrar seus danos da Prefeitura. Blog de Paulo Vinícius Coelho, 2 abr. 2013. Disponível em: <http://espn.uol.com.br/post/320217_melhor-cenario-para-obotafogo-nao-e-entregar-engenhao-mas-cobrar-seus-danos-da-prefeitura $>$. Acesso em 30 jul. 2014.

75. RONALDO será tema de Carnaval de SP. De prima, 13 jun 2013. Disponível em: http://blogs.lancenet.com.br/deprima/2013/06/13/ronaldo-sera-tema-de-carnavalem-sp/. Acesso em 26 mai. 2014.

76. PRADO, Renato Maurício. Estrelas também choram. O blog do Renato Maurício Prado, 07 mai. 2013. Disponível em: http://oglobo.globo.com/esportes/rmp/ posts/2013/05/07/estrelas-tambem-choram-495695.asp. Acesso em 29 mai. 2014.

77. Campanhas pela reabertura do Engenhão foram bastante divulgadas em blogues de torcedores. Cf. HABIB, Lucas. \#EduardoPaesDevolvaNossolEstadio. Aliança Alvinegra, 28 mai. 2013. Disponível em: <http://www.aliancaalvinegra.com/2013/05/ eduardopaesdevolvanossoestadio $>$. Acesso em 4 ago. 2014.

78. Contribuiçõos importantes poderiam ser dadas por pesquisas sobre as rotinas produtivas que levassem em consideração a formação profissional/acadêmica, a formação afetiva e os processos de aquisição de conhecimento dos jornalistas esportivos. Suspeitamos que a formação e as características estruturais da atuação profissional (produzir um noticiário muito fragmentado, construído em cima de uma rotina repetitiva de cobrir treinos, viagens, jogos e competiçôes) possam ser fatores explicativos que contribuam para análises mais complexas. Contudo, faltam trabalhos científicos consistentes a respeito.

79. Para um bom trabalho de Comunicação abordando torcedores comuns, ver Vimieiro (2014). 